\title{
Effects of Heavy Metal Pollution on Women in Coal Mining Areas
}

\author{
Munmi Borgohain ${ }^{1}$, Dr. M. Gopal Singha ${ }^{2}$ \\ ${ }^{1}$ Research Scholar, Department of Geography, Gauhati University, Assam, India \\ ${ }^{2}$ Former HOD\& Associate Professor, PG Department of Geography, Bikali College, Dhupdhara, Goalpara, Assam, and Research \\ Supervisor Dept. of Geography, Gauhati University, India
}

\begin{abstract}
Ledo coal mineis situated in North-eastern part of India. It is a small place situated in Tinsukia district. Its geographical area covers from $27^{0} 17.272$ ' $N$ \& $95^{\circ} 45.012^{\prime} \mathrm{E}$ (Tapadar, et al., 2015). A Ledo is a part of Makum coalfields, which is an opencast type of mine. Due to large excavation and production of coal in this area manylabours, and people are engaged, thus it is possible that some problem regarding human relation with coal mine will arise. Among those problem a serious problem has come into light about the women livelihood in coal mining areas. Likewise, in Ledo coal mine many women's livelihood have been in threat. So, in this paper an effort has been made to study the impact on women livelihood in Ledo coal mining area. For this study interview of women workers in Ledo coal mine were taken. Also, some statistical methods were also applied in nearby Ledo coal mine villages to get an accurate result of the study. For preparation of maps GIS technique was used along with the study area toposheet.
\end{abstract}

Keywords: Women livelihood, Ledo coal mine, female workers

\section{Introduction}

Ledo is a small town situated at a short distance from Margherita in Tinsukia district of Assam. It covers an area from $27^{0} 17.272$ ' $\mathrm{N} \& 95^{\circ} 45.012^{\prime} \mathrm{E}$ (Tapadar, et al., 2015). The Ledo area comprises of 11717 population (Census of India 2011), among which maximum number of people are engaged in Ledo coal mine.Ledo area is well known for its Opencast coal mine. Ledo coal mine is a part of the biggest coalfield, i.e. the Makum coalfield. Ledo coal mine was started in 1884 when British-owned Assam Railways and Trading Company (ARTC) (District Census Handbook, Tinsukia 2011). In Ledo coal mines many both gender employees are engaged here. During the processing of excavation of coal mines both gender workers are found to be involved. The society prevailing in this coal mining area are somewhat like the other coal mining areas. According to this society the male and female labourers had to come across discrimination in various phases. Such as wages are paid less to female workers in comparison to male workers. Females are exploited by different levels of people. So, in this study we have given main emphasis on the impact of women livelihood in Ledo coal mine. Relating to various primary and secondary sources a certain conclusion has been drawn on the Impact of women livelihood in coal mines. In order to get an accurate result and to figure out the real scenario of the impact of coal mines in the women livelihood interviews in depth with was held within the people engaged in the coal mines and also in the nearby sample village areas in Ledo. For secondary information various sources such as district Census Handbook of Tinsukia (2001 and 2011), Statistical handbook of India, various articles, and thesis were reviewed.

\section{Objectives}

This paper aims:

1) To throw light and in-depth study on the Impact of coal mine on women livelihood in Ledo coal mine area.
2) To study the catalytic role of women folk play in industrial area.

3) To study the changes in women livelihood caused due to development in industrial sector.

4) To analyze the occupational and professional difficulties faced by the working women in the study area.

\section{Methodology}

To fulfill the objectives of the study both primary and secondary data has been used. While collecting primary data in order to analyze the real picture, personnel interview has been taken. For presentation and analysis of data statistical methods has been used and for preparation of maps toposheets and GIS technology has been used.

\section{Analysis}

According to Census of India 2011, (District Census Handbook, Tinsukia) the Population of Ledo town is 11717. This population of Ledo are divided into certain category marginal workers, main workers, cultivators, agricultural labourers, other workers and non-workers, according to 2011 census. But here for this paper we are focusing on workers so marginal and main workers are considered. Since the study is focusing on the livelihood of women in Ledo coal mining area so, the women main and marginal workers are being taken for considering or analyzing the aspect of. In order to support the study on women livelihood a sample survey has been conducted in Ledo coal para area, which is near by the Ledo coal mine, to get the accurate result of the study. In this coal mine maximum number of people are engaged.

Table 1: Number of Main workers, Marginal workers and Non-workers in Ledo coal mine.

\begin{tabular}{|c|c|c|c|c|c|}
\hline $\begin{array}{c}\text { Sl. } \\
\text { No. }\end{array}$ & $\begin{array}{c}\text { Name of } \\
\text { the town }\end{array}$ & $\begin{array}{c}\text { Total } \\
\text { population }\end{array}$ & $\begin{array}{c}\text { Main } \\
\text { workers }\end{array}$ & $\begin{array}{c}\text { Marginal } \\
\text { workers }\end{array}$ & $\begin{array}{c}\text { Non- } \\
\text { workers }\end{array}$ \\
\hline 1 & Ledo & 11717 & 3360 & 441 & 7916 \\
\hline
\end{tabular}

Source: Primary Survey and Secondary data 
Table 2: Number of Main workers, Marginal workers and Non-workers (males and females) in Ledo coal mine.

\begin{tabular}{|c|c|c|c|c|c|c|c|c|c|}
\hline \multirow{2}{*}{ Sl. No. } & \multirow{2}{*}{ Name of the town } & \multicolumn{2}{|c|}{ Total population } & \multicolumn{2}{c|}{ Main workers } & \multicolumn{2}{c|}{ Marginal workers } & \multicolumn{2}{c|}{ Non-workers } \\
\cline { 3 - 10 } & & Males & Females & Males & Females & Males & Females & Males & Females \\
\hline 1 & Ledo & 6028 & 5689 & 2976 & 5689 & 320 & 121 & 2732 & 5184 \\
\hline
\end{tabular}

\section{Source: Primary Survey and Secondary data}

While surveying it has been found that Ledo total population is 11717 (according to 2011 census) and to get accurate result of analysis this population has been divided into workers (3801) and non-workers (7916). In this area the workers are further divided into marginal workers (441) and main workers (3360). The number of non-workers is more in comparison to workers because of the improved technology in the industrial areas' workers got replaced by machines. These nonworkers are not unemployed they are handful numbers of agricultural labourers, cultivators, mill workers and businessmen.

Table 3: Number of Main workers, Marginal workers and Non-workers in Ledo coal Para (Surveyed Sample village)

\begin{tabular}{|c|c|c|c|c|}
\hline $\begin{array}{c}\text { S. } \\
\text { No. }\end{array}$ & $\begin{array}{c}\text { Name of the } \\
\text { town }\end{array}$ & Houses & $\begin{array}{c}\text { Total } \\
\text { population }\end{array}$ & $\begin{array}{c}\text { Total } \\
\text { workers }\end{array}$ \\
\hline 1 & Ledo coal para & 470 & 2148 & 889 \\
\hline
\end{tabular}

Source: Primary Survey and Secondary data

Table 4: Number of Main workers, Marginal workers and Non-workers (Males and Females) in Ledo coal Para (Surveyed Sample village)

\begin{tabular}{|c|c|c|c|c|c|c|c|}
\hline $\begin{array}{c}\text { S. } \\
\text { No. }\end{array}$ & Houses & Population & Male & Female & $\begin{array}{c}\text { Total } \\
\text { workers }\end{array}$ & Male & Female \\
\hline 1 & 470 & 2148 & 1121 & 1027 & 889 & 694 & 195 \\
\hline
\end{tabular}

Source: Population census 2011

In order to get an accurate result of the study a sample areahas been surveyed which is near by the Ledo coal mine known as Ledo coal para. According to population census 2011 Ledo coal para area has total 470 households out of which 100 households has been surveyed by following systematic random sampling method.

Systematic random sampling formula for interval (i) $=\mathrm{N} / \mathrm{n}$ Whereas $\mathrm{g}, \mathrm{N}=$ size of the population

$\mathrm{n}=$ size of the sample

Here $\mathrm{N}=470$

$\mathrm{n}=100$

$\mathrm{i}=470 / 100=4.7$

Here approximately 5 is taken as interval.

So, according to the statistical method every interval of 5 houses survey was carried on for 100 households out of 470 houses in sample area.

Table 5: Population details of surveyed sample village

\begin{tabular}{|l|l|l|l|l|}
\hline Household & Population & Male & Female & Children \\
\hline 100 & 515 & 240 & 152 & 123 \\
\hline
\end{tabular}

Source: Primary Survey

A village nearby Ledo coal mine has been surveyed where with the help of statistical method 100 households has been surveyed. The population among 100 households was 515, further this population has been divided into male, female and children category. As we are focusing on the effect of coal mine on women so further survey was carried on about the total number of workers, which was further categorized as workers in mine, miscellaneous workers and these
Workers are further divided into female and male workers which is shown in table no. 6 .

Table 6: Workers details of surveyed sample village (Ledo Coal para)

\begin{tabular}{|c|c|c|c|c|}
\hline $\begin{array}{c}\text { Total } \\
\text { workers }\end{array}$ & $\begin{array}{c}\text { Workers } \\
\text { in mine }\end{array}$ & $\begin{array}{c}\text { Miscellaneous } \\
\text { workers }\end{array}$ & $\begin{array}{c}\text { Male } \\
\text { workers }\end{array}$ & $\begin{array}{c}\text { Female } \\
\text { workers }\end{array}$ \\
\hline 292 & 162 & 130 & 190 & 102 \\
\hline
\end{tabular}

Source: Primary Survey

In the sample village during the survey it was found that total number of workers are 292. Among these workers mine workers are 162, whereas other 130 workers are engaged in miscellaneous works. Among the workers in mines which is shown in table no. 7, 102 are male whereas female is only 60 in numerical in the sample village.

Table 6: Details of workers in mines in surveyed sample village (Ledo Coal para)

\begin{tabular}{|c|c|c|}
\hline $\begin{array}{c}\text { Total mine } \\
\text { workers }\end{array}$ & $\begin{array}{c}\text { Male workers in } \\
\text { mine }\end{array}$ & $\begin{array}{c}\text { Female workers in } \\
\text { mine }\end{array}$ \\
\hline 162 & 102 & 60 \\
\hline
\end{tabular}

Source: Primary Survey

According to the data collected during the survey only an average number of females are engaged in the mine. These women are designated in various post. Only a handful of females works in office and rest of them are engaged in mining activities in mining areas. In the early era most of the females were engaged in underground mines which was active during those periods of time. Women use to carry excavated coal in baskets from underground mining areas to dumping areas due to lack of technology as compared to male workers. But during wage there was always a discrimination among the genders even after the workload was same, which is a very important concern and a very sensitive topic of discussion as in any economic establishment. The discrimination got a boost as since history women were treated inferior to men.If we Look back in the early stage of Industrial revolution, since that decade women proved to be equal as compared to men(Datta, 1991). Due to poverty and also due to lack in skillswomen are forced to work in minor activities in coal mines, this led them always agreed to work at low wage, which further gave rise to various sources to earn money beside working in coal mine. Even though women workers in coal mines proved to be equal as men but they were neve $r$ provided safety during their service. They had to take risk of their life while being an employee in coal mines. Thus, some women out of fear got involved themselves in daily markets. They use to sell vegetables, home-made bidis and liquor, forest resources such as fruits, vegetables, herbs etc. Gradually the women workers in coal mines began to decrease due to incoming development of coal mine technologies, which forced the women to involve themselves in various illegal business, such as, producing local liquor which is very harmful, also forced in prostitution activities, etc. 
But now along the passing decades the thoughts of people along with technologies got developed and came up with an act of equality of wages among all workers abide of gender discrimination in all industrial sector. This act brought an act of relief among all workers. While surveying the sample area women are satisfied with the rules and regulation along with the benefits provided for women workers in coal mines. Women are now taken care in all fields such as health, safety, social and cultural sectors, etc. Women among the surveyed sample area are found to be in better designation in comparison to men. Which is a positive sign of the growth of the society.

Here will see some examples of sign of safety benefits provided to the women workers in coal mines as interviewed in sample surveyed area.

1) Women during the duty hours are provided safety kits wherever necessary. Usually at present period women are not designated in underground mining activities as it includes lots of risk to life.

2) Women are taken care of their health which is proved where various health camps through CSR programs are carried out. These programs spread awareness in different areas among the people. Awareness such as during pregnancy period, menstrual periods, married life, various health issues which is common in women life.

3) Women are acknowledged about various upcoming skills in the society for better future which would make them self-dependent. Such as switching classes, various handicraft classes, safety classes for mining workers, first aid programs, etc.

\section{Conclusion}

After performing the survey in the sample area, here a conclusion can be made that along with the passage of time everything is going along its flow of development. People are developing both mentally, culturally as well as technological development are also carried on. Women from its dense evil days are arising to a better day. They are now not buried under any social boundaries or not forced under social evil rules and regulation. Women are now free to earn their living and can support their family which ultimately led to establish their own identity as they are now equally skilled in comparison to men. They are now aware of various activities and their both positive and negative outcomes. The word "Discrimination" is no longer present in the social dictionary of todays coal mine industry society. Women had overcome the bias behavior in the society which their old parents and grandmothers had to suffer inhabiting near the coal mining areas during British period. So we can say that negative effects of coal mine had came to its lowest percentage in comparison to positive effects.

\section{Reference}

[1] Das, N (2015): "Socio-economic Impact of Mining on Rural Communities: A Study of the Ib Valley Coalfield in Odisha", A Ph.D. published thesis submitted to National Institute of Technology in Rourkela.

[2] Datta, M (1991): "Socio-Economic conditions of women workers in coal mines in Asansol area", A Published $\mathrm{Ph}$. D thesis submitted to University of Calcutta.
[3] District Census Handbook, Tinsukia, Assam (2011).

[4] Dutt, K.L. (2003), "Informal coal mining in eastern India: Evidence from the RaniganjCoal belt”, Natural Resources Forum 27, pp. 68-77.

[5] Guimbeau, A. et. al. (2020): "Mining and Gender Gaps in India", IZA Institute of Labor Economics, DP No. 13881.

[6] Jha, N (2015): "Coal Mining and Rural Ecology: A Study in Talcher, Odisha", A M.A thesis submitted to National Institute of Technology in Rourkela.

[7] Sharma, S (2010): "The impact of mining on women: lessons from the coal mining Bowen Basin of Queensland, Australia. 'Impact Assessment and Project Appraisal, 28(3), September, pages 201-215.

[8] Singh, R. (2015): "Mining and Its Impact on Tribals in India: Socio -Economic and Environmental Risks" International Journal of Social Science and Humanities Research, 3(2), 429-439.

[9] Taabazuing, J. et. al. (2012): "Mining, conflicts and livelihood struggles in a dysfunctional policy environment: the case of Wassa West District, Ghana" African Geographical Review, 31(1), 33-49. http://doi.org/10.1080/19376812.2012.69008 